\title{
Modern Concepts of Cultural Sociodynamics \\ in the Context of Research \\ of the Socio-Cultural Environment \\ of the Indigenous Peoples of the North, \\ Siberia and the Far East
}

\author{
Natalia P. Koptseva* \\ Siberian Federal University \\ 79 Svobodny, Krasnoyarsk, 660041, Russia
}

Received 23.04.2015, received in revised form 07.07.2015, accepted 19.10.2015

The article reveal the methodological opportunities of the modern concepts of sociodynamics of culture of A. Moles, W. Weidlich, G.M. McLuhan, M. Castells for modelling and predicting genesis of the socio-cultural space of the indigenous peoples of the North, Siberia and the Far East. The unique cultural phenomena of these ethno-cultural groups will find a new life with the use of the modern information technologies.

Keywords: ethno-cultural groups, A. Moles, W. Weidlich, G.M. McLuhan, M. Castells, sociodynamics of culture, Northern territories, indigenous people.

DOI: 10.17516/1997-1370-2016-9-1-68-78.

Research area: culture studies.

\section{Introduction}

In 2006, Siberian Federal University set up the Chair for Cultural Studies and carried out the first admission of students in the "Cultural studies" speciality, in 2007 - in the degree program of "Cultural Studies". From the very first steps of existence and development the Chair for Cultural Studies has been combining teaching of theoretical series of academic disciplines with research work in theory and methodology of cultural studies. The Chair operates a scientific workshop "Theory and practice of applied Cultural Studies". Contemporary cultural studies are important in relation to how they can be applied and used in various forms of sociocultural practices. For the Krasnoyarsk Territory the socio-cultural development of its Northern territories inhabited by the indigenous peoples of the North and Siberia is of special importance. Currently, 8 ethno-cultural groups occupy a special cultural place in the region: the Evenki, the Enets, the Nganasans, the Dolgans, the Kets, the Selkups, the Chulyms and the Nenets. In the modern world science the Northern territories located above the Arctic Circle, where the indigenous peoples live, are called "circumpolar

(C) Siberian Federal University. All rights reserved

* Corresponding author E-mail address: decanka@mail.ru 
territories". The Russian Federation has the most extensive circumpolar territories in the world. A cultural space of these areas is unique and has special sociodynamics. Scientists and graduate students studying at the Chair for Cultural Studies, Siberian Federal University, have been doing a great deal of theoretical and applied work related to the study of this cultural space for several years already. The culturologists organized and held 6 complex ethno-cultural expeditions to the places of compact settlement of the indigenous peoples of the Krasnoyarsk Territory and brought unique materials that are still being processed and the results of which are being published in scientific journals and collective monographs.

Peoples of the circumpolar territories are the study object of almost all the modern humanities and social sciences: philosophy, cultural anthropology, sociology, linguistics, history, ethnic psychology and others. A conceptual and methodological context of the research issues related to their sociocultural reproduction and development can be divided into two plans: 1) the social existence of ethnoses of the circumpolar territories is considered as an aspect of the more complex social processes (e.g., as a specific aspect of the social "minority" existence); or 2) the ethno-cultural groups of the indigenous peoples of the North are considered as a special object of the socio-humanities knowledge having inner integrity and unique logic of social development. But in both cases a scientific search is initiated by the complex socio-economic and sociocultural issues typical of these ethnic and cultural groups.

Problems of preserving the unique sociocultural space of the indigenous peoples of the North, Siberia and the Far East require integration of various liberal arts: philosophy of culture, theory and methodology of culture, ethnology, social and cultural anthropology, cultural history, cultural linguistics. Methodological research strategies of this cultural space are also of great importance.
They must be based on a systematic approach implying that the socio-cultural space of the indigenous peoples of the North, Siberia and the Far East is based on the traditional nature management and the variety of economic and cultural practices that retain their languages. However, the traditional nature management of these ethno-cultural groups has a limit to the growth of their quality of life. Often, the traditional nature management can only provide a very low level of quality of life, especially for those ethno-cultural groups that are occupied with nomadic reindeer breeding, collecting wildgrowing herbs, fishing and hunting.

Currently, there is an urgent need to develop specific models of socio-economic and sociocultural development of the indigenous peoples of the North, Siberia and the Far East, where cultural values and ideals of these ethnic groups are being "covered" with a modern shell, primarily a digital one. They are preserved through special government support measures in relation to the unique cultural heritage: folklore, languages, arts and crafts, architecture with elements of ethnomythological symbols, etc.

In recent decades, in the information space of different countries, regions and cultural groups there is a concept of the circumpolar civilization a particular type of socio-economic and sociocultural development of ethnic and cultural groups living above the Arctic Circle. We are talking about areas in such countries as the USA, Norway, Sweden, Russia and Canada. And although the concept itself is controversial, debatable and nonrecognized, we must note the special ecological compatibility of the cultural space of the Northern peoples, their harmonious co-existence with the severe nature of the North, tundra, forest-tundra and taiga.

Currently, there is reindustrialization of the Northern and Arctic Regions of the Russian Federation is going on. It is known that the indigenous peoples of the North, Siberia and the 
Far East are particularly vulnerable to the foreigncivilization influence, which the industrialization brings to places of their traditional compact settlement. A multicultural society, which is the society of the Russian Federation, requires a special value attitude to the cultures of small-numbered peoples, needs a special government support related to the modern practices of virtualization of the unique cultural heritage, digitization of visual and audio culture of the indigenous peoples.

It seems that an interdisciplinary approach has a particular importance in the research of the cultural space of the Northern ethnic and cultural groups. There is a need to make the most serious study of philosophical-cultural and culturalanthropological, conceptual and methodological grounds: approaches, concepts and models of socio-cultural reproduction and development applied for the study of the preservation and development of the peoples of Northern and Arctic territories of the Russian Federation.

Up to the present moment there has been importance of the classical philosophical and cultural-anthropological approaches to ethnocultural issues, which have been developed by scientists throughout the $19^{\text {th }}-21^{\text {st }}$ centuries and have been associated with philosophy of culture, philosophy of values, theory of culture, social and cultural anthropology. The study of the philosophical models of sociocultural reproduction of ethnoses is all the more important because the philosophical models of a prognostic nature ensure the success of applied research and shorten the path to their practical implementation. This article attempts to identify a group of cultural concepts that could make an effective methodological basis for studying a socio-cultural environment of the indigenous peoples of the Krasnoyarsk Territory and even broader - the indigenous peoples of the North, Siberia and Far East of the Russian Federation.

\section{Modelling cultural sociodynamics} in the studies of $\mathrm{A}$. Moles

\section{("Sociodynamics of culture"), W. Weidlich}

("Sociodynamics: a systematic approach

to mathematical modelling

in the social sciences") and

\section{G.M. McLuhan ("The Gutenberg Galaxy: The Making of Typographic Man")}

The ethno-cultural groups compactly living in the Northern and Arctic regions of the Russian Federation have peculiar socio-cultural dynamics. Their ethno-cultural genesis differs significantly from the other ethnic and cultural groups, including the socio-cultural dynamics of the Aboriginals of Australia and North America. Although Russia began the processes of colonization simultaneously with Portugal and Britain, unlike in these states that lost their colonies in the $20^{\text {th }}$ century, the Russian state develops its Northern territories not as colonies, but as an integral part of its country and its ancestral territory. However, the cross-cultural differences between the urbanized sociocultural space of most Russian ethno-cultural groups and the traditional socio-cultural space of the indigenous peoples of the North, Siberia and the Far East are so great that now it became necessary to design sociodynamics of these peoples' cultures. It seems that for this purpose we can use the model proposed by the famous French researcher Abraham Moles.

Abraham Moles in his work titled "Sociodynamics of culture" [Moles, 2008] proposes to manage the development of sociocultural cycles through the mass media. Such a model of socio-cultural management could be fruitfully applied in the socio-cultural design of life processes of the indigenous peoples of the North. In this case, the first step should be the study of the specificity of cultural dissemination cycles through various communication channels typical of the studied ethnic groups, identification 
of the relevant cultural systems, distribution channels, message ideas of culture, semantic and aesthetic content of these messages, forms of communication, etc. The next step should be modelling of specific cycles of cultural dynamics for each channel and each ethos. For example, it is obvious that for the indigenous peoples of the North living in distant areas a socio-cultural cycle of a theatre will not be appropriate due to its inaccessibility, but a socio-cultural cycle of a musical message may be acceptable. Therefore, each ethnic group can create its own system of socio-cultural cycles that are mediated by certain mass-communication tools. Meanwhile, each ethnic group has its own cultural table and is characterized by its specific memory of the world. I.e. the impact of cycles of disseminating the culture will always be applied to this particular socio-cultural table, and it is likely that one ethnic group will demand some aspects of the culture message, and in another - other aspects of the same message, and in the third one a cultural message will not be necessary at all. After identifying these specifics, it will be necessary to explore the channels of mass communication, through which one or another ethnos can be influenced (for example, not in all cases television can be influential due to the lack of television sets or air signal failure, etc.). Further, it will be necessary to build possible schemes of control over the ethnic culture through transmitting certain messages of culture with certain ideas through certain masscommunication tools.

The second model that can be used for establishing modern sociodynamics of the indigenous peoples of the North, Siberia and the Far East is a model that was created and developed by Wolfgang Weidlich.

In his work titled "Sociodynamics. A systematic approach to mathematical modelling in the social sciences" [Weidlich, 2010] Wolfgang Weidlich proposes to use mathematical modelling techniques to predict development scenarios of not only a biological or physical, but also a social system. His work consistently proves the possibility of such an approach using analogies between these three types of systems and their study. However, the author emphasizes the complexity of the study of social systems as compared with others, suggests that the elements of any social system are complex systems themselves that are in a relationship of self-consistency and dependence. In connection with such a complex organization of social systems socio-dynamic modelling acquires a number of specific characteristics: the modelling is only possible on a meso- and macro-level, to sort out variables needed to describe a model is quite difficult, sometimes the social system is so complicated that it cannot be described by a single model, in this connection we have to choose the most necessary aspect of the system to build the model.

Weidlich examines the types of variables needed to create the model, and then reveals the features of creation of socio-dynamic models by the example of four social systems - demography (migration), sociology, economics and regional science.

The approach proposed by W. Weidlich and designated as sociodynamic modelling can be successfully applied in the study of the Northern indigenous peoples' culture. Moreover, the application of this method is seen in the various fields of culture of the indigenous ethnic groups: in the field of demography and forecasting indigenous population of the Northern territories, in the field of economics - the study of the possibilities and prospects of the development of traditional crafts (reindeer breeding, hunting, processing and manufacturing of antlers, fishery), in education, in the field of preservation of national cultural heritage (language, mythological concepts, applied arts and crafts), in the study 
of social structure, social stratification and prospects of social development of the indigenous peoples, etc. The Weidlich method involves not only the study of the current situation in all these areas of culture of the indigenous peoples of the North, Siberia and the Far East, but also allows you to model possible scenarios of the dynamics of a particular social system and to predict the possibility of development of each scenario, and thus, to draw conclusions about the highest probability of some of them and, if necessary, to take preventive measures in order to reduce the probability of negative scenarios and increase the probability of developing positive scenarios.

However, for the implementation of this method it is necessary to attract a large group of experts from various fields of scientific knowledge required to conduct a preliminary qualitative research and detect necessary configurations of variables.

In the $60-70 \mathrm{~s}$ of the $20^{\text {th }}$ century many talented researchers visualized the beginning of the new stage in the history of mankind, which eventually became known as the "information age". Quite heuristic models that could be used for the social construction of ethno-cultural identities through fundamentally new technologies already appeared at the very beginning of modelling the upcoming information age.

One of such models was created in the $60 \mathrm{~s}$ of the $20^{\text {th }}$ century by G.M. McLuhan who in his book "The Gutenberg Galaxy. The Making of Typographic Man” [McLuhan, 2003] identified three types of transmitting a socio-cultural experience: preliterate, book (which he called "the Gothenburg Galaxy") and electronic.

G.M. McLuhan believes that a modern human has invented many "extensions" of all parts of his body. For example, the evolution of weapons begins with claws and fists and ends with an atomic bomb. Clothes that a person wears and houses in which people live become an extension of the mechanism of thermoregulation. However, for these technical devices a person pays the price of the impossibility to go beyond a single system. Human abilities to perceive are not closed systems, but move from one into the other. However, technological tools are always closed systems that are incapable of to interaction or collective awareness.

Up until the invention of the written language, people have been immersed in the space of the spoken language, which was literally woven into the actions and view of the world of a primitive man. McLuhan notes that this is why the perception of the world in people of the preliterate cultures was mainly determined by sensation and hearing. He defines the world of a human of the preliterate culture as an "audio-universe", the natural and harmonious. The world beyond this audio-universe could only be cognized intuitively. When the written language appeared as the dominant means of communication, the left hemisphere of the human brain began to develop at the expense of the right one. When the natural and harmonious spoken "tribal" culture (according to McLuhan, a culture of the "tribal type of society") ends, an era of the alphabet and absolute power of visual objects begins. This resulted in the phenomena of de-collectivization and individualism. The invention of the alphabet switched the centre of human perception from hearing to vision - for humanity it meant the entry into the mechanistic era. According to McLuhan, only the phonetic alphabet can divide an eye and an ear, the semantic meaning and the visual code, only writing can transform a "tribal" person into "civilized". Under the "civilized" man McLuhan means such a person for whom the visual values are primary in organizing thoughts and actions.

McLuhan uses the concept of "civilization" not as the opposite to a "lower" notion of "noncivilization". On the contrary, he describes 
"civilized" people as more primitive than those cultures characterized by spoken and audio languages.

The scientist says that the modern society fosters conformism starting from the early childhood and explains why the ancient manuscript culture and culture of the Middle Ages did not cultivate conformism unlike the "printed" culture. The most important characteristic of the manuscript culture is its relative unity. Consequence of the rarity and inaccessibility of manuscripts was the development of encyclopedism. Scientists were few, they were all well known. Manuscripts were studied slowly and aloud, so reading the manuscripts was close to the oral discourse. With the invention of the printing press the number of scientists increased and, as a consequence, their value decreased, and the same happened with books. The emergence of the printing press sparked a shift from encyclopedism to specialization. According to McLuhan, a detonator for the "technology explosion" was a goose quill, and the epicentre of the explosion was the invention of the printing press by Johannes Gutenberg. Since that time, the processes of separation of society into separate fragments begin, and, according to McLuhan, from this point the Western world is constantly moving in the direction towards a greater separation of senses, functions and actions. This process was initiated by the fact that the printed word allowed to explore the world individually, outside the community and its collective consciousness. Besides, the book became the first standard reproducible item, the first result of mass production. "Invention of the alphabet, like invention of the wheel, was a transfer or reduction of the complex organic interaction of semantic fields to a single semantic field. The phonetic alphabet immediately reduced the use of all meanings that were in the spoken language to a simple visual code. Today, such a transfer can be made in different ways through different forms that we call "means of communication". But each of these meanings has unique properties relative to our other senses or meanings" [McLuhan, 2003, p. 45].

In today's "electronic age" human consciousness became fastened to a closed global video communications system, which promotes the development of the right hemisphere of the brain. Our entire planet acquires an image of "the global village" - a new civilization, the electronic "tribal" society. The new electronic interdependence recreates the world in the image of the global village. Electronic technology is a means of resolving cultural and ideological differences and contradictions. Today's generation lives in a transitional period of refusal from stagnation of "the Gutenberg era" and evolves under the influence of a direct electronic explosion" [McLuhan, 2003, p. 39].

McLuhan writes that throughout history mankind has sought to expand the capabilities of the human body (the ability to fly, swim underwater, communicate across large distances, etc.). Today, in the age of electronic technologies, we can extend our "central nervous system to the whole planet", so such concepts as "space" and "time" become irrelevant. However, humanity is quickly approaching the final stage of this "extension" - the technological imitation of consciousness that arises due to the fact that creativity is no longer a privilege of the individual and becomes a collective process. In the mechanical era a transfer from a person's action to reaction to this action often took a very long time. In the present, a human's action and response are performed at the same time, although a person's thinking is still fragmentary. In the electronic age, when the human central nervous system got its continuation, the response to any action is almost instant and humanity constantly has to deal with the consequences of its actions. 
The world turns into a "global village", in which information is spread instantly. Social minorities acquire the fullness of their rights for the first time, as the information about them becomes known, and the social majority can no longer ignore their problems. McLuhan argues that the electronic-information society has much more common features with the tribal society than the "Gutenberg era", since modern communication channels enable to return to the wholeness of the world perception that was lost with the advent of the printing press.

The most important characteristic of a new type of society is that the means of communication is a message itself. For example, an electric bulb itself is a message because electric light creates an environment just by its presence.

McLuhan's ideas are seemed to be correct in relation to the main means of mass communication, which, then, McLuhan did not know about - the Internet. Today, a computer, as confirmed by the assumption of McLuhan, has already become an extension of our consciousness. And McLuhan's ideas about the global village, which the planet turns into, with a tendency to dissolve the state formations, destruct language barriers and eliminate huge distances across continents have become almost a reality.

On the other hand, McLuhan does not mention the back side of the creation of this "global village", which is the advocacy of the national, ethnic communities, cultures and territories.

The McLuhan's concept may be useful in the study of the indigenous cultures of the North if the central direction of researchers will be the McLuhan's assertion that the modern electronic-information society in its characteristics and consciousness is much closer to the tribal society than the "Gutenberg era", namely by the integrity of perception. In connection with this, a huge part of culture of the indigenous peoples of the North (language, religion, mythology, art culture, symbolic content, lifestyle, thoughts and activities) can be understood and studied thoroughly enough. On the other hand, according to the McLuhan's model, the representatives of the indigenous peoples of the North, Siberia and the Far East should be more comfortable to adapt to the electronic-information society.

\section{The concept of cultural sociodynamics of M. Castells ("The Information Age: Economy, Society and Culture", "The INTERNET Galaxy")}

If the model of G.M. McLuhan is mainly associated with the problems of sociodynamics of cultures at the transition from the spoken language to the written one and to the domination of the visual objects, with criticizing "the Gutenberg Galaxy" that broke the centuries-old social ties and built new cultural hierarchies, then the model of Manuel Castells is strongly associated with the "INTERNET galaxy" [Castells, 2004; . Castells, 2000]. Although G.M. McLuhan predicted that a new stage of socio-cultural changes would be connected with a return to the original social integrity, but it turned out that the new "galaxy" has brought with it not only new kinds of cultural communication, but also has set new problems: how did culture, relationships between people and the structure of our daily lives change? What new social and cultural groups are formed within the "INTERNET galaxy"? What fate do the indigenous peoples of the North, Siberia and the Far East await in this new reality?

An original feature of the M. Castells' model is associated with the identity of technology and society. He argues that technology and society are inextricably connected and that in fact they are the same. New information technologies are extremely "human" because for the first time a person's generic ability to produce signs and symbols becomes a direct productive force of 
social systems. Symbolic understanding of the world distinguishes a human from other living systems, and now it turns into a real basis of society creating specific forms of economy, social communication and cultural spaces. Information technologies generate an economic and political power, break local states and lead to the emergence of the global socio-cultural space, the structure of which is the offspring of the information technologies.

Manuel Castells examines new forms of economy - e-business and e-economy as a whole, virtual communities, network society, Internet policy, its geography. The Internet culture that for the first time really "takes over" the whole planet and shows multicultural layers that constitute the reality of the global socio-cultural space is of particular importance for our study. According to Castells, culture that exists in the national forms still does not destroy a single technological matrix, in accordance of which there are production, distribution and consumption. In addition, communication serves as one of the forms of existence of the socio-cultural space. Currently, it is undergoing dramatic changes related to the integration of different information systems into a single interactive unit. An affordable integrated, interactive global communication system creates a new cultural "hypertext", where the oral and written communication, audio and visual objects, different forms of national cultures exist in a single point of a person's immediate presence. Anthropolic shifts associated with the dominance of this "hypertext" are still elusive, although it is clear that all the cultural codes are greatly influenced by this "hypertext", and not only various kinds of business and economics are forced to adapt to it, but also the traditional religions and the indigenous ethno-cultural groups.

The ethno-cultural space of the indigenous peoples of the North, Siberia and the Far East will irreversibly change within this planetary socio-cultural, technological revolution. We could suggest that in the near future the ethnocultural space of the Northern indigenous peoples will only have a virtual reality because the traditional nature management will fail to meet the vital needs of the ethno-cultural groups that want to have the same quality of life as the industrial urban society. And then the very notion of the unique culture of the indigenous peoples of the North will have an electronicdigital form given to folklore, arts and crafts, religious and mythological systems typical of these ethno-cultural groups.

In his model Manuel Castells describes in detail the changes that occur with the forms of culture that have been associated with the mass media. Until the $80 \mathrm{~s}$ of the $20^{\text {th }}$ century the media was a way to organize transmission of cultural texts. In the $80 \mathrm{~s}$ of the $20^{\text {th }}$ century the mass media undergo interesting changes: on the one hand, the audience of the traditional and non-traditional media becomes incredibly huge - hundreds of millions and billions of people. On the other hand, the mass media significantly differentiate both the content and the form of information presentation in accordance with the local cultural spaces. In this regard, some researchers say that they can no longer be called "mass" in the old sense of the term.

These changes in the media have special significance for the indigenous peoples of the North, Siberia and the Far East. The possibility of multiple and locally-oriented cultural texts in ethnic languages becomes a reliable mechanism for the preservation of the unique languages of the Northern peoples. Thus, in the Taimyr Dolgan-Nenets municipal district there are radio stations in 5 languages of the indigenous peoples of the Krasnoyarsk Territory. Unfortunately, there are no more print publications. But it seems that only organizational issues hinder their 
emergence. Economic reasons no longer justify the lack of the printed and television media in the national languages of the indigenous peoples of the North. Currently, the media audience is extremely segmented, interactive technology are becoming more effective for the media as well. Representatives of the indigenous peoples of the North, Siberia and the Far East can act as creators and organizers of cultural texts in local language, as well as their translators. Work on the internet support in the areas of compact settlement of the ethno-cultural groups could solve the problem of unemployment that is still more acute for the Northern territories than for the other regions of the Russian Federation.

Segmentation of the audience of the modern media in the context of a new round of development of the unique cultures of the indigenous Northern peoples does not mean that the modern interactive media avoid the influence of political subjects, including the effect of various aspects of the public policy. On the contrary, the state through the government interactive media gets additional opportunities to implement various government programs, including the state program for the sustainable development of the indigenous peoples of the North, Siberia and the Far East. Currently, there is a definite information deficit. Not all the members of these ethnic and cultural groups have a well-developed legal culture that gives them knowledge of those preferences that the state has provided these peoples for.

At the same time, the translation of cultural texts of the indigenous peoples of the North and the Far East via the modern media is effectively complemented by another aspect in the modern information society, which is emphasizes by Manuel Castells. E-mail, chats, virtual social networks can give new life to the spoken language expressed in the native language of the indigenous Northern peoples. A number of researchers believe that, on the contrary, the written language takes revenge, where the original spoken language is transformed by a certain rational discourse. It seems that the electronic technologies can create a new kind of speech that is different from the previous oral and the former written. This new kind of speech integrates in itself a certain form. Thus, in the context of modern cultural linguistics we could set a topical research problem connected with how the native languages of the indigenous peoples of the North are adapted to such transformations. As a hypothesis, we can assume that it will take certain efforts of a particular group of volunteers who want to preserve and develop their native languages that in the form of a certain cultural value will contribute to the development of new interactive communications in the native language.

We should also pay attention to the Castells' idea that new technologies not only create new social structures, but also identify ripened needs of the existing social structures and thereby strengthen these social structures. As applied to social structures of the indigenous peoples of the North, Siberia and the Far East this idea can be applied as follows: it is now possible to fix a fairly intensive processes associated with the formation of national elites that, on the one hand, perform traditional political, elite functions as heads of clans and tribes, and on the other hand, act as intermediaries between the ancestral communities of the indigenous peoples and the real state power in the Russian Federation. Sociologists and political scientists note some attempts of this national elite to consciously restrain economic and cultural development of tribal communities to retain their own power and exceptionally enjoy all those preferences that the state gives to all the members of the community, and the heads of the clans have learned to use these preferences in their favour. 
New electronic and information technologies contribute to the development of distant forms of education in the remote areas of the Northern territories. The development of education will undoubtedly contribute to the processes associated with the increased requirements (both material and spiritual) of the majority of the indigenous peoples of the North, Siberia and the Far East. It is possible that in this regard the negative consequences of legal illiteracy will gradually decrease, and also the parasitic possibilities of some representatives of national elites to usurp state funds intended for all the representatives of the indigenous peoples will be decreasing.

It seems that the implementation of the M. Castells' model will lead to a series of changes in the socio-cultural environment of the ethnocultural groups:

1) Virtual ethno-cultural communities consisting of representatives of the indigenous peoples of the North, Siberia and the Far East will be created. They will use specific cultural signs and symbols that are typical of these nations, as well as the oral and written language of these peoples will get a new life;

2) new social and professional strata in the environment of these ethno-cultural groups will emerge; thus, the national elite will consist not so much of the hereditary heads of clans, but also of young people who have mastered the ITtechnologies and able to create a virtual network communities, including by the ethno-cultural feature; e-business and e-economy are little connected with the environment, including the harsh Northern nature; the emergence of new professional groups will lead to the qualitative socio-cultural growth of the Northern cultural groups without giving up the unique cultural values and standards that, on the contrary, become distinctive features of these virtual communities;
3) being an element of the "hypertext" in the INTERNET, cultural texts (old and new) of the indigenous peoples will find new readers in the global network and in the future may lead to the emergence of carriers of unique cultures of the Northern peoples among the communities that were not carriers of these cultures initially.

Today's global cultural space has an urgent need in "fresh" cultural images, in new and unique cultural texts. Cultural codes of the indigenous peoples of the North, Siberia and the Far East can make effective impetuses to create these unique cultural texts. At their culturallinguistic decipherment the complex languages of the studied ethno-cultural groups open new cultural worlds that will occupy a special place in a large multicultural community, in the large "global village" that, in fact, has already been established and continues to be built by new "global regions".

Thus, the current socio-cultural space of the indigenous peoples of the North, Siberia and the Far East is being formed on the verge of resolution of the main contradiction: the contradiction between the unique traditional cultural values fixed in the traditional nature management, on the one hand, and the modern cultural practices, the domination of which is based on the rapid development of information technologies, on the other hand. It seems that the resolution of this contradiction will lead to the creation of modern information forms of the socio-cultural space of these peoples. The social structure will reveal their characteristic tendencies through virtualization and the cultural codes will get a new life in the network space and modern information practices. Information technologies can become impetuses for the creation of new work places in the Northern territories. A new professional environment in these regions of the Russian Federation will contribute to the economic development of the Northern territories and show 
the effects of the unique cultural practices of the of human communities and the native land of the Northern peoples built on the harmonious unity North.

\section{References}

Castells, M. Galaktika Internet [The INTERNET Galaxy]. Yekaterinburg: U-Faktoriya with the participation of University for the Humanities, 2004. 328 p.

Castells, M. Informatsionnaya epokha. Ekonomika, obshchestvo i kultura [The Information Age. Economy, Society and Culture]. M: HSE, 2000. 608 p.

McLuhan, G.M. Galaktika Gutenberga. Sotvoreniye cheloveka pechatnoi kultury [The Gutenberg Galaxy: The Making of Typographic Man]. M.: Nika-center, 2003. 432 p.

Moles, A. Sotsiodinamika kultury [Sociodynamics of culture]: Translated from French. B.V. Biryukov. $3^{\text {rd }}$ edition. M.: LKI Publishing house, 2008. 416 p.

Weidlich, W. Sotsiodinamika: sistemniy podkhod $\mathrm{k}$ matematicheskomu modelirovaniyu $\mathrm{v}$ sotsialnikh naukakh [Sociodynamics. A Systematic Approach to Mathematical Modelling in the Social Sciences]. Trasnlated from English. Ed. Yu.S. Popkov, A.E. Semechkin. $2^{\text {nd }}$ edition, stereotypical. M.: Book House "LIBROKOM”, 2010. 480 p.

\section{Современные концепции социодинамики культуры}

\section{в контексте исследования}

\section{социально-культурного пространства \\ коренных малочисленных народов Севера,}

Сибири и Дальнего Востока

Н.П. Копцева

Сибирский федеральный университет Россия, 660041, Красноярск, пр. Свободньй, 79

Раскрываются методологические возможности современных концепциий соцуиодинамики культуры А. Моля, В. Вайдлиха, Г.М. Маклюэна, М. Кастельса для моделирования и прогнозирования генезиса сочиокультурного пространства коренных малочисленных народов Севера, Сибири и Дальнего Востока. Уникальные культурные феномень этих этнокультурных групп найдут новую жизнь с помощью современных информационньх технологий.

Ключевые слова: этнокультурные группь, А. Моль, В. Вайдлих, Г.М. Маклюэн, М. Кастельс, социодинамика культуры, северные территории, коренные народы.

Научная специальность: 24.00.00 - культурология. 